\title{
TINGKAT PENGETAHUAN REMAJA TENTANG ROKOK HISAP SHISA DI SMK SENOPATI SEDATI SIDOARJO
}

\author{
Zaenal Abidin ${ }^{1}$, Septi Ayu Maulidia ${ }^{1}$ \\ 'Akademi Keperawatan Kerta Cendekia Sidoarjo
}

Corresponding: -

\begin{abstract}
Abstrak
Introduction. Banyak inovasi - inovasi baru yang telah diciptakan oleh masyarakat dan untuk masyarakat. Namun tidak semua inovasi tersebut membawa dampak baik untuk kelangsungan hidup manusia, salah satu contohnya adalah rokok hisap shisa.Fenomena yang terjadi adalah masih banyak pengguna sisha yang tidak mengetahui tentang pemahaman arti shisa serta bahaya dari mengonsumsi rokok hisap shisa secara berlebihan.Tujuan peneliti ini adalah untuk mengetahui tingkat pengetahuan remaja tentang rokok hisap shisa di SMK Senopati Sedati Sidoarjo. Methods. Penelitian ini adalah penelitian deskriptif, Populasi dalam peneliti ini berjumlah 40 responden. Teknik sampling penelitian ini menggunakan tehnik total sampling, dengan jumlah sampel 40 responden. Variabel penelitian ini adalah tingkat pengetahuan remaja tentang rokok hisap shisa. Data di ambil dengan kuesioner, kemudian di olah dan di analisis dengan data distribusi frekuensi. Results. Hasil penelitian menunjukkan bahwa terdapat 6 responden yang mempunyai pengetahuan baik, 13 responden mempunyai pengetahuan yang cukup serta 21 responden mempunyai pengetahuan kurang tentang rokok hisap shisa. Discussion. Tingkat pengetahuan yang kurang tersebut dapat dipengaruhi oleh factor diantaranya : usia, jenis kelamin, pernah / tidaknya mendapat informasi, dan sumber informasi. Dari hasil masalah tersebut dapat di atasi dengan meningkatkannya pengetahuan remaja tentang rokok hisap shisa dengan melakukan kerjasama dengan tim kesehatan terdekat untuk memberikan penyuluhan tentang rokok hisap shisa kepada remaja.
\end{abstract}

Keywords: Remaja, pengetahuan, rokok hisap shisa

\section{Pendahuluan}

Pada zaman modern ini sudah banyak inovasi inovasi baru yang telah diciptakan oleh masyarakat dan untuk masyarakat. Namun tidak semua inovasi tersebut membawa dampak baik untuk kelangsungan hidup manusia, salah satu contohnya adalah rokok hisap shisa. Meskipun shisa sudah dikenal berabad silam di Timur Tengah yang kini kembali tren khususnya dikalangan anak muda. Karena selama ini banyak orang beranggapan menghisap shisha aman dan tidak merusak kesehatan. Namun jangan salah, shisha rupanya memiliki efek yang sama buruknya dengan merokok. Kandungan tembakau pada shisa lebih tinggi daripada tembakau rokok pada umumnya, jadi dapat dibayangkan betapa berbahanya apabila terlalu banyak memgonsumsi shisa. Pengertian dari shisha itu sendiri adalah sejenis alat yang digunakan untuk mengeluarkan asap dengan air sebagai penyaring. Berbeda dengan rokok, shisha atau hookah memiliki rasa yang beraneka ragam, seperti buah-buahan, mint, kopi, semua menjadi sensasi dan daya tarik bagi yang menghisapnya (Robert, 2012). Apalagi dikalangan pelajar laki-laki SMK bahkan perempuan saat ini sudah lebih menyukai rokok hisap shisa daripada merokok cigaret. Sebuah studi yang dihajat Mohammad Hossein Boskabady dari Universitas Ilmu Kedokteran di Iran menunjukkan, shisha sama berbahayanya dengan rokok bagi paruparu. Dampak paling sederhana adalah gangguan pernapasan. Fenomena yang terjadi disalah satu kedai shisa adalah masih banyak pengguna sisha yang masih bersekolah dengan menggunakan seragam lengkap sedang menikmati rokok hisap shisa secara beramairamai. Yang sebagian pelajar tersebut berasal dari SMK Senopati. Mereka pun tidak mengetahui tentang pemahaman arti shisa serta bahaya dari mengonsumsi rokok hisap shisa secara berlebihan. Bagi mereka, jika tidak tahu dan tidak pernah menikmati shisha rasanya mereka bukan anak gaul seperti teman-teman lainnya, selain itu harga shisa tersebut relatif murah dengan kisaran harga Rp 35 ribu per bong, shisha dapat dinikmati sekitar 1-2 jam secara beramai-ramai. Karena pada kenyataannya siswa remaja tersebut hanya mengetahui tentang kenikmatan rasa shisa serta efek tenang setelah mengonsumsi rokok hisap shisa tersebut dan banyak pelajar SMK yang mengklaim shisha lebih aman karena asap melewati air sehingga sebagian besar bahan kimianya akan diserap. Namun hingga sekarang tidak ada bukti yang mendukung teori tersebut.

\section{Metode dan Bahan}

Pada penelitian ini desain penelitian yang digunakan adalah penelitian deskriptif. Tujuan dari penelitian ini adalah untuk mengetahui tingkat pengetahuan remaja tentang rokok hisap shisa. Penelitian ini dilaksanakan di SMK Senopati Sedati, Sidoarjo. Dalam penelitian ini menggunakan non probability sampling tipe total sampling, sehingga Sampel dari penelitian ini adalah semua remaja pengguna rokok hisap shisa di SMK Senopati yang berjumlah 40 remaja. Dalam penelitian ini yang menjadi variable penelitian adalah pengetahuan siswa tentang bahaya rokok hisap shisa. Pada penelitian ini 
instrument yang digunakan berupa kuesioner yang diberikan kepada responden. Kuesioner dalam penelitian ini diartikan sebagai daftar pertanyaan yang dibuat oleh peneliti dan dijawab oleh responden (Hidayat, 2003). Tiap pertanyaan terdiri dari 2 option jawaban yang berupa closed-ended tipe multiple choice dengan soal berjumlah 10 buah pertanyaan. Dalam pertanyaan tersebut responden hanya memberi tanda silang (x) pada salah satu jawaban yang dianggap benar. Tehnik pengumpulan data pada peneliti ini adalah menggunakan angket untuk mengetahui tingkat pengetahuan remaja tentang bahaya rokok hisap shisa. Sebelum angket diisi responden diberi penjelasan terlebih dahulu tentang cara pengisian kuesioner. Pembagian kuesioner dilakukan secara langsung oleh peneliti, setelah di isi angket diminta kembali untuk di beri kode sesuai dengan nomor urut responden, dan setelah itu hasil jawaban dari angket tersebut segera di tabulasi.

\section{Hasil Penelitian}

Berdasarkan hasil penelitian didapatkan data yang menunjukkan bahwa hampir seluruhnya responden mempunyai tingkat pengetahuan kurang yaitu sebanyak $21(52,5 \%)$ responden.

\section{Pembahasan}

Berdasarkan hasil penelitian yang dilakukan di SMK Senopati Sedati, Sidoarjo pada Tanggal 20 Maret 2014 terhadap 40 responden diperoleh hasil bahwa hampir seluruhnya responden yang mempunyai tingkat pengetahuan kurang yaitu sebanyak 21 remaja $(52,5 \%)$ responden. Responden pada penelitian ini menunjukkan bahwa mereka masih mempunyai pengetahuan yang kurang tentang rokok hisap shisa, dimana pengetahuan responden ini kurang diperoleh dari penyuluhan yang dilakukan oleh tenaga kesehatan. Pengetahuan responden ini dapat terjadi karena dipengaruhi oleh faktor umur, jenis kelamin, pendapatan informasi dan sumber dari informasi.

Berdasarkan hasil penelitian didapatkan data yang menyebutkan bahwa dari 40 responden yang berusia 17 tahun terdapat 10 responden ( $25 \%$ ) mempunyai tingkat pengetahuan kurang, kemudian responden yang mempunyai tingkat pengetahuan cukup yaitu sebanyak 5 responden $(12,5 \%)$ responden dan responden yang mempunyai tingkat pengetahuan baik yaitu sebanyak 2 responden $(5 \%)$ responden. Berdasarkan hasil penelitian di atas, peneliti berpendapat bahwa usia tidak mempengaruhi tingkat pengetahuan seseorang. Seharusnya seseorang dengan usia 17 tahun mempunyai tingkat pengetahuan yang baik terhadap sesuatu di bandingkan dengan usia 16 tahun, selain itu seseorang dengan usia 17 tahun seharusnya mempunyai tanggapan intelektual, dan kemampun belajar yang masih baik sehingga tingkat pengetahuannya juga akan baik. Namun pada kenyataannya responden yang berusia 17 tahun mempunyai tingkat pengetahuan kurang tentang rokok hisap shisa. Pada anak usia remaja ini mereka merasa telah mampu membuat keputusan berdasar pada prinsip yang dimilliki dan diyakininya, apapun tindakan yang diyakininya dipersepsikan sebagai suatu kebaikan. Jadi, semakin baik motivasi dan informasi yang diberikan, maka tingkat pengetahuan seseorang juga akan semakin baik, dan semakin cukup umur, maka bertambah pula ilmu serta informasi yang didapat baik dari luar maupun dari dalam sehingga ilmu dan informasi tersebut dapat menambah pengetahuan seseorang. Hal ini di dukung teori menurut Hurlock (2003) yang mengatakan semakin dewasa umur seseorang, tingkat pematangan dan kekuatan seseorang akan lebih matang dalam berfikir dan bekerja serta konstruktif dalam menggunakan koping. Di samping itu juga semakin cukup umur maka pengalaman yang didapat dan kematangan jiwa semakin baik.

\section{Simpulan}

Hasil penelitian mengenai tingkat pengetahuan remaja tentang rokok hisap shisa diperoleh data bahwa hampir seluruhnya remaja di SMK Senopati Sedati Sidoarjo mempunyai tingkat pengetahuan kurang yaitu sebanyak $21(52,5 \%)$ responden. Ddengan adanya hasil penelitian ini diharapkan remaja lebih aktif bertanya kepada petugas kesehatan tentang rokok hisap shisa sehingga dapat meningkatkan pengetahuan remaja tentang rokok hisap shisa dan dampaknya. Selain itu, harus adanya ketersediaan informasi yang memadai dari petugas kesehatan dalam memberikan semua informasi kesehatan yang dibuthkan oleh remaja.

\section{Daftar Pustaka}

Agoes, Dariyo (2000). Psikologi Perkembangan Dewasa Muda. Jakarta: PT. Grasio Anggota

Ananda, Kun Silla (2012). Shisha Sama Buruknya dengan Rokok. www.google/shisa/blogs. Diakses tanggal 5 Oktober 2013, pada pukul 16.10 WIB

Boskabady, Hossein (1999). Respirology. www.tempo.com. Diakses pada tanggal 5 Oktober 2013, pada pukul 17.00 WIB

Dariyo. (2004). Konsep Remaja. Bandung:Pustaka Setia

Hurlock, (2003). Faktor internal yang mempengaruhi pengetahuan. http://en.wikipedia.org. Diakses pada tanggal 30 September 2013 pada pukul 19.45 WIB

Lusia. Anna (2012). Bahaya shisa. www.google.com. Diakses tanggal Jumat, 12 November 2013, pada pukul 10.13 WIB

Nasrul Efendy (2002). Dasar-dasar Keperawatan Kesehatan Kesehatan Remaja. Jakarta: EGC

Notoatmojo, Soekidjo (2002) Metodologi Penelitian Kesehatan. Jakarta : Rineka Cipta

Notoadmojo, Soekidjo (2003). Ilmu Kesehatan Masyarakat. Jakarta ; Rineka Cipta

Nursalam (2002). Manajemen Keperawatan. Jakarta : Salemba Medika

Nursalam (2003). Konsep \& Penerapan Metodologi Penelitian Ilmu Keperawatan Pedoman Skripsi, Tesis dan Instrumen Penelitian Keperawatan. 
Jakarta : Salemba Medika

Nursalam, M. (2005). Jurnal Ners. Surabaya : FK Unair

Paris, Terry. (1999). Metro Detroit Hookah Scene. www.google.com. Diakses pada tanggal 27 Oktober 2013, pada pukul 13.00 WIB

Soetjianingsih. (2004). Pertumbuhan Somatik Pada Remaja. Jakarta:Sagung Seto

Setiadi. (2007). Konsep Dan Penulisan Riset Keperawatan. Jogjakarta:Graha Ilmu 